UDC 881.111: 378.147.091.3

\title{
EFFICIENCY TESTING OF EXPERIENTIAL ESP INSTRUCTION TO FUTURE SYSTEM ANALYSTS
}

\author{
Z. M. Kornieva, I. V. Pavlovska \\ Kyiv, National Technical University of Ukraine \\ "Kyiv Polytechnic Institute" \\ julia_pavlovska@ukr.net
}

\begin{abstract}
The article deals with the topical problem of introducing the experiential methodology into the process of teaching English at technical tertiary schools. The backgrounds of the methodology mentioned are analyzed; the process of implementing the general and narrow professionalization into English instruction is described. General English professionalization aims at simultaneous combination of several elements of teaching, which are taught separately under the current curriculum and also have separate time allocation. These components include the improvement of general English competence, as well as general and narrow professionalization of English instruction. The authors describe the stages of efficiency testing of experiential ESP instruction using the new textbook "Professional Basics". The study is suggested to be organized on the basis of the aspected approach, which stresses the necessity in studying such components as subject, sociolinguistic, linguistic, psychological and communicative aspects. The factual results of the experiment and estimation of the proposed methodology efficiency are given. It is stated that the textbook and the methodology proved their high efficacy in learning outcomes - all groups showed the general increase in all types of communicative activities. The outcomes of the questionnaires completed by the students after the experimental study under the proposed methodology are also presented.
\end{abstract}

Key words: experiential learning, general English professionalization, ESP, aspected learning

Introduction. Nowadays all technical tertiary schools of Ukraine operate under curriculum which presupposes English for Specific Purposes instruction to students majoring in different fields of study, including System Analysis. This demand is set by current official documents (Bucharest Communiqué, English for Specific Purposes National Curriculum for Universities) as well as the Common European Framework of Reference for Languages, and a number of universities curricula in act [1]. The problem of professionally oriented English instruction at tertiary schools for many years has been in the scope of the researches of both Ukrainian (O. Bigych, N. Borysko, S. Nikolayeva, O. Tarnopolsky) and foreign scientists (J. Crandal, M. Wesche, N. Cloud, J. Cummins, R.K. Johnson, M. Swain etc).

Usually the above mentioned programs propose the widespread among Ukrainian universities scheme of ESP acquisition, which aims at forming communicative competence in General English during the first two years of study. Only after that, during the third year of study, the students move on to learning professionally oriented English, under general and narrow specialization.

Nevertheless, such approach is not always effective, especially when it comes to students who enter the university with already well-developed General English communicative competence. Such students feel no need to learn General English further, but strive to develop professionally oriented English competence right from the first year of study at tertiary schools. Thus, of particular interest and topicality nowadays are the researches and the developments of new methodologies which could propose a well-balanced and grounded combination of teaching both General English and ESP from the first year of study. 
The aim of our article is to present the results of the experimental testing of experiential methodology of ESP instruction, conducted during the first year of study of students majoring in System Analysis. In order to reach this goal, the following tasks have been set: to define the notion of the experiential methodology of teaching, to explain its efficacy and its place in teaching ESP to future system analysts, to present the learning outcomes and the results of questionnaires of students after the experimental study under the methodology proposed.

Learning process organization. In order to solve the problem of ESP teaching on the first stages of study at tertiary schools, we propose to organize the learning process according to the following procedure:

1. general English professionalization during the first year of study;

2. narrow English professionalization - starting from the second year of study.

Under 'general English professionalization' we understand the process of acquiring the competence in general aspects of professional English communication, which are common for most technical jobs. Narrow English professionalization means learning English, tailored for very specific field of operation, e.g. for future system analysts or engineers.

The stage of general English professionalization ( $1^{\text {st }}$ year of study) aims at simultaneous combination of the several components of study, which are taught separately under the current curriculum and also have separate time allocation. These components include the improvement of general English competence, as well as general and narrow professionalization of English instruction.

We propose to combine these components in the course of general English professionalization, which should be taught in aspects. [2]. These aspects include the following:

1. Content focus (aiming at incorporating the understanding of future profession, creating the professionally oriented sphere of communication, developing formal and logical competence).

2. Sociolinguistic focus (aiming at the development of sociolinguistic and pragmatic components of communicative competence, as well as at the development of socio-cultural component of formal and logical competence);

3. Linguistic focus (aiming at forming the linguistic and pragmatic components of communicative competence as well as at the development of linguistic component of formal and logical competence);

4. Psychological focus (aiming at developing psychological competence which contributes to the psychologically adequate English communication);

5. Communicative focus (aiming at combining all the mentioned above components in the communication process).

In every cycle of lessons, which are to be integrated by the topical factor, the focus is gradually shifted from aspect to aspect. In the course of each topical cycle of lessons, all five aspects of study are covered. Each aspect is paid special attention and approximately the same amount of time should be allocated for the study of each aspect.

The content of study. Another very important component of introducing the general English professionalization and then - narrow English professionalization into teaching ESP is the selection of learning content. As was mentioned above, in the course of general English professionalization it is advisable to select the topics, which could cover the wide spheres of professional communication, typical for most 
technical professions. The analysis has shown that in their work the specialists of most engineering professions commonly deal with the following topics:

1. Telephoning

2. Writing for Professional Purposes

3. Enterprise Structure

4. Professional Negotiations

5. Informative and Persuasive Presentations

6. Corporate Advertising

7. Ordering goods and equipment

8. Delivery of the goods and equipment

9. User manuals for goods and equipment

10.International agreements

11.Exhibitions

12.Project organization and financing.

The concept of experiential study. The leading methodology, which creates the opportunity to reach the goals stated, is experiential methodology of English teaching - the main component of constructive approach to language teaching.

In the background of the experiential methodology of teaching English lies the concept of so-called 'learning by doing', developed by J. Dewey at the beginning of the XX century [3]. This methodology gained special popularity in the latest decade in the American practice of teaching English as a second language. After J. Dewey we define the experiential study as the study through experience of practical activities, which are conducted by means of the language learnt [4].

The methodology mentioned above forms the background of the new textbook "Professional Basics", developed by O.B. Tarnopolsky, Z.M. Kornieva and their colleagues. The effectiveness of the study using this textbook was tested in the course of the experiment, conducted at the National Technical University of Ukraine "Kyiv Polytechnic Institute". In the experiment 5 groups of students took part, all of them studying at the Institute of Applied System Analysis. The total number of participants accounted for 84 students of the first year of study. It should be mentioned that no special selection of students was carried out, the lessons were given under usual conditions, one lesson per week in groups of 15-17 students. The total time of study accounted for 36 academic hours. The experimental study was traditionally organized into three stages: entry test, study itself and exit test.

The entry test was given at the first lesson of the semester. It included the tasks for the estimation of the level of students' competence in all four types of communicative activities: listening, reading, writing and speaking. The results of the entry test (see Table 1) allowed distinguishing three types of groups of students (using the terminology of C.A. Tomlinson [5]), namely, groups of advanced learners, groups of struggling learners, and groups of intermediate learners. To the group of advanced learners, whose level of English is slightly higher than B1 belongs group K-1; to the groups of intermediate learners with the level B1 belong groups K-2, K-3 and K-4; to the group of struggling students with level lower than B1 belongs group K-5. The differentiation into these groups was made purely with the aim of estimating the efficacy of the methodology and the textbook under different conditions.

The results of the experimental study. The experimental study was conducted according to the recommendations given in the textbook and according to the principles and peculiarities of the methodology proposed. During the semester (36 
academic hours) 6 topics were studied, namely, "Telephoning", "Writing for Professional Purposes", "Professional Negotiations", "Enterprise Structure", "Informative and Persuasive Presentations", "Corporate Advertising". At the lessons such types of learning activities were used as role play, presentations, discussion of the content of study etc. The students were also assigned to work in groups on the project and their results were discussed in the end of the semester. Most students were active during the study; they applied a creative approach to communicative tasks, especially when doing projects and role-playing. It should be mentioned that in the struggling groups of students the learning process was somewhat complicated, additional time should have been allocated to explain to the subject background of the methodology.

The outcomes of the experimental study conducted according to the methodology proposed are illustrated by the results of the exit test. The procedure of the exit test was the same as the procedure of the entry one. In order to estimate the increase in the level of communicative competence students were asked to complete the tasks in listening, speaking, reading and writing. The tasks of the exit test were analogical to the tasks of the entry test, the scales and criteria of estimation were also the same. The results of both entry and exit tests of experimental study are given in Table 1. The table presents the average rates of each group (the average number of scores and the average percentage of correct answers).

Table 1. The Results of Testing the Level of Communicative Skills in Speaking, Writing, Listening and Reading

\begin{tabular}{|c|c|c|c|c|c|c|c|c|c|c|}
\hline & \multicolumn{2}{|c|}{ Speaking } & \multicolumn{2}{|c|}{ Writing } & \multicolumn{2}{|c|}{ Listening } & \multicolumn{2}{|c|}{ Reading } & \multicolumn{2}{|c|}{ Total } \\
\hline Scores & \multicolumn{2}{|c|}{$\begin{array}{l}\text { The average } \\
\text { score in group } \\
\text { (out of 15), \% }\end{array}$} & \multicolumn{2}{|c|}{$\begin{array}{l}\text { The average } \\
\text { score in group } \\
\text { (out of 12), \% }\end{array}$} & \multicolumn{2}{|c|}{$\begin{array}{l}\text { The average } \\
\text { score in group } \\
\text { (out of } 8 \text { ), \% }\end{array}$} & \multicolumn{2}{|c|}{$\begin{array}{l}\text { The average } \\
\text { score in group } \\
\text { (out of 15), \% }\end{array}$} & \multicolumn{2}{|c|}{$\begin{array}{l}\text { The average } \\
\text { score in group } \\
\text { (out of } 50 \text { ), \% }\end{array}$} \\
\hline Test & I & II & I & II & I & II & I & II & I & II \\
\hline Gr. K-1 & $\begin{array}{c}10 \\
(66,7 \%)\end{array}$ & $\begin{array}{c}12,9 \\
(86 \%)\end{array}$ & $\begin{array}{c}9 \\
(75 \%)\end{array}$ & $\begin{array}{c}11,2 \\
(93,3 \%)\end{array}$ & $\begin{array}{c}5,5 \\
(68,8 \%)\end{array}$ & $\begin{array}{c}6,9 \\
(86,3 \%)\end{array}$ & $\begin{array}{c}8 \\
(53,3 \%)\end{array}$ & $\begin{array}{c}12,5 \\
(83,3 \%)\end{array}$ & $\begin{array}{c}32,5 \\
(65 \%)\end{array}$ & $\begin{array}{c}43,5 \\
(87 \%)\end{array}$ \\
\hline Gr. K-2 & $\begin{array}{c}9,9 \\
(66 \%)\end{array}$ & $\begin{array}{c}11,9 \\
(79,3 \%)\end{array}$ & $\begin{array}{c}7,8 \\
(65 \%)\end{array}$ & $\begin{array}{c}8,9 \\
(74,2 \%)\end{array}$ & $\begin{array}{c}3,1 \\
(38,8 \%)\end{array}$ & $\begin{array}{c}6,1 \\
(76,3 \%)\end{array}$ & $\begin{array}{c}6,3 \\
(42 \%)\end{array}$ & $\begin{array}{c}11,7 \\
(78 \%)\end{array}$ & $\begin{array}{c}27,1 \\
(54,2 \%)\end{array}$ & $\begin{array}{c}38,6 \\
(77,2 \%)\end{array}$ \\
\hline Gr. K-3 & $\begin{array}{c}9,4 \\
(62,7 \%)\end{array}$ & $\begin{array}{c}11,4 \\
(76 \%)\end{array}$ & $\begin{array}{c}7,1 \\
(59,2 \%)\end{array}$ & $\begin{array}{c}9,6 \\
(80 \%)\end{array}$ & $\begin{array}{c}3,4 \\
(42,5 \%)\end{array}$ & $\begin{array}{c}5,9 \\
(73,6 \%)\end{array}$ & $\begin{array}{c}5,6 \\
(37,3 \%)\end{array}$ & $\begin{array}{c}11,8 \\
(78,7 \%)\end{array}$ & $\begin{array}{c}25,5 \\
(51 \%)\end{array}$ & $\begin{array}{c}38,7 \\
(77,4 \%)\end{array}$ \\
\hline Gr. K-4 & $\begin{array}{c}10 \\
(66,7 \%)\end{array}$ & $\begin{array}{c}12 \\
(80 \%)\end{array}$ & $\begin{array}{c}6,3 \\
(52,5 \%)\end{array}$ & $\begin{array}{c}7 \\
(58,3 \%)\end{array}$ & $\begin{array}{c}3,9 \\
(48,8 \%)\end{array}$ & $\begin{array}{c}4,9 \\
(61,3 \%)\end{array}$ & $\begin{array}{c}5,3 \\
(35,3 \%)\end{array}$ & $\begin{array}{c}11 \\
(73,3 \%)\end{array}$ & $\begin{array}{c}25,5 \\
(51 \%)\end{array}$ & $\begin{array}{c}34,9 \\
(69,8 \%)\end{array}$ \\
\hline Gr. K-5 & $\begin{array}{c}9 \\
(60 \%)\end{array}$ & $\begin{array}{c}10,4 \\
(69,3 \%)\end{array}$ & $\begin{array}{c}6,8 \\
(56,7 \%)\end{array}$ & $\begin{array}{c}7,8 \\
(65 \%)\end{array}$ & $\begin{array}{c}3,2 \\
(40 \%)\end{array}$ & $\begin{array}{c}4,6 \\
(57,5 \%)\end{array}$ & $\begin{array}{c}5,7 \\
(38 \%)\end{array}$ & $\begin{array}{c}10,9 \\
(72,7 \%)\end{array}$ & $\begin{array}{c}24,7 \\
(49,4 \%)\end{array}$ & $\begin{array}{c}33,7 \\
(67,4 \%)\end{array}$ \\
\hline
\end{tabular}

The results of the entry and exit tests show substantial increase in all four types of communicative activities in all groups of students - advanced, intermediate and struggling. The best results were achieved in the development of reading skills (from $53 \%$ to $83 \%$ in advanced group, from $35-42 \%$ to $73-78 \%$ in intermediate groups, and from $38 \%$ to $73 \%$ in struggling group) and listening skills (from $69 \%$ to $86 \%$ in advanced group, from $38-48 \%$ to $61-76 \%$ in intermediate groups, and from 40 to $58 \%$ in struggling group). High increase is also achieved in the development of speaking skills - from $67 \%$ to $86 \%$ in advanced group, from $63-67 \%$ to $76-80 \%$ in intermediate groups and from $60 \%$ to $70 \%$ in struggling group. Sustained increase of $10-20 \%$ can 
be observed in the skills of writing among all groups. Thus, the textbook and the methodology proved their high efficacy in learning outcomes - all groups showed the general increase of 20-25\% in all types of communicative activities.

In order to prove the efficacy of the textbook from students' point of view a interview was conducted after the experimental study. The questions in the questionnaire aimed at revealing students' attitude towards the textbook and the methodology in general. The results of the questionnaire in all groups show that $83 \%$ of students are satisfied with the textbook; $75 \%$ of students believe that the tasks in the textbook are creative and help to develop learning potential; $81 \%$ of students think that the content of learning is interesting and useful; $81 \%$ reckon that the tasks of the textbook give enough independence and allow individual variation; $70 \%$ of students have felt sustainable growth of their English communicative competence after every lesson; $64 \%$ of students believe that the textbook has created effective learning environment and positive atmosphere.

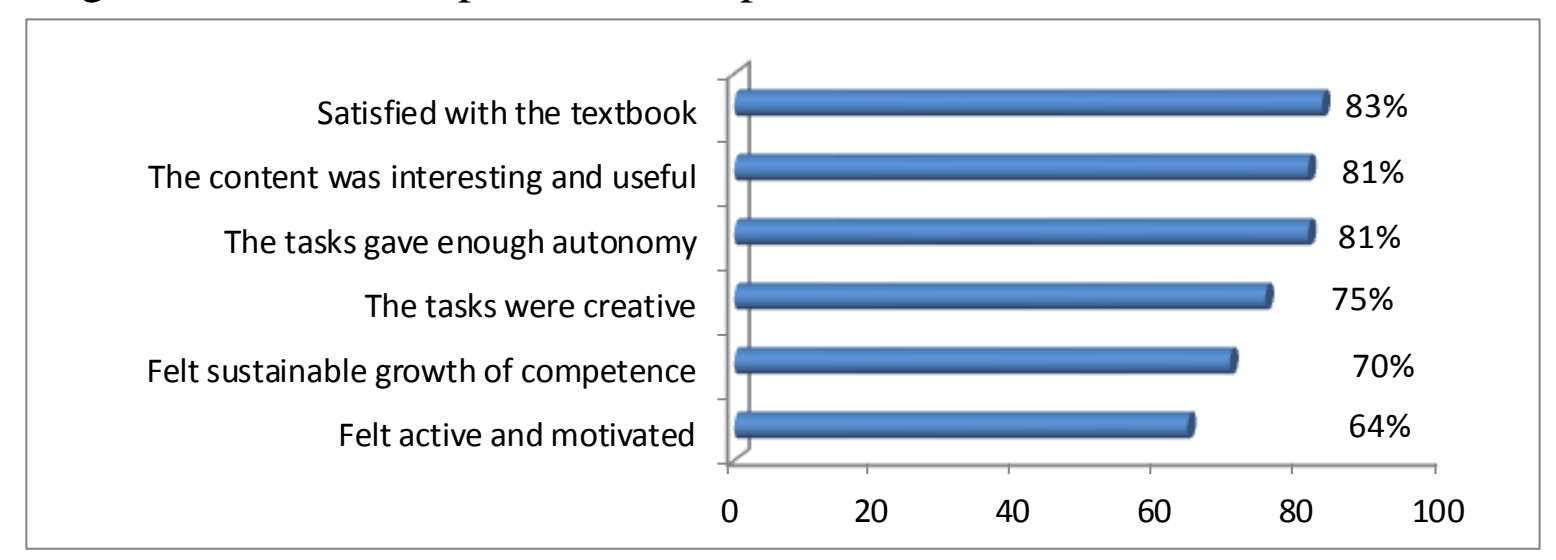

Diagram 1. The results of the questionnaire

Thus, the results of the questionnaire illustrate the high level of their satisfaction with the textbook, which proves the assumption that the textbook is able to motivate students to study.

Conclusions. Taking into consideration the practical results mentioned above, we can state that the methodology proposed has proved to be effective for ESP instruction to future system analysts both in outcomes and motivation aspects. The perspective of future studies in this sphere lies in experiential methodology implementation in the instruction of students of other specialties.

\section{REFERENCES}

1. Загальноєвропейські Рекомендації 3 мовної освіти: вивчення, викладання, оцінювання / Наук. ред. українського видання С.Ю. Ніколаєва. К.: Ленвіт, 2003. - 273 с.

2. Тарнопольський О.Б., Корнєва 3.М. Аспектний підхід до навчання англійської мови для спеціальний цілей у немовних ВНЗ / З.М. Корнєва, О.Б. Тарнопольський // Викладання мов у вищих навчальних закладах на сучасному етапі: зб. наук. праць. - Х., 2011. - Вип.18. - С. 231-239.

3. Dewey J. Experience and education / John Dewey . - NY: Collier, 1938. - 345 p.

4. Kolb D. Experiential learning: Experience as the source of learning and development/ David Kolb . - Englewood Cliffs, NJ: Prentice Hall, 1984. - 248 p.

5. Tomlinson C.A. Leading and Managing a Differentiated Classroom / Tomlinson C. A., Imbeau M. B. - Alexandria: Association of Supervision and Curriculum Development, 2010. - 187 p. 


\section{REFERENCES}

1. Nicolayeva, S.Y. (Ed.) (2003). Common European Framework of Reference for Languages. Kyiv: Lenvit [in Ukrainian].

2. Tarnopolskyi, O.B., Kornieva Z.M. (2011). Aspected approach to ESP instruction at technical tertiary schools Scientific journal "Vykladannya mov u vyshchykh navchal'nykh zakladakh na suchasnomu etapi”, 18, 231-239. Kharkiv, Ukraine [in Ukrainian].

3. Dewey, J. (1938). Experience and education. NY: Collier.

4. Kolb, D. (1984). Experiential learning: Experience as the source of learning and development. Englewood Cliffs, NJ: Prentice Hall.

5. Tomlinson, C.A., Imbeau M. B. (2010). Leading and Managing a Differentiated Classroom. Alexandria: Association of Supervision and Curriculum Development.

3. М. Корнсва, Ю. В. Павловська. Експериментальна перевірка ефективності використання експеріснційної методики навчання англійської мови студентів напряму підготовки «Системний аналіз».

Стаття присвячена актуальній проблемі застосування експерієнційної методики у процесі навчання англійської мови у вищих навчальних закладах немовного профілю. Автори пропонують використовувати вищевказану методику для загальної іншомовної професіоналізації навчання англійської мови, тобто для забезпечення оволодіння студентами загальними аспектами професійної іншомовної комунікації, спільними для більшості немовних спеціальностей. Виходячи із компонентного складу іншомовної комунікативної компетентності, професійно орієнтовану англійську мову пропонується викладати аспектно. Серед таких аспектів автори виділяють предметний, соціолінгвістичний, лінгвістичний, психологічний та комунікативний аспекти навчання англійської мови. Експерієнційне навчання визначається як навчання через досвід практичної діяльності, яка здійснюється засобами виучуваної мови. Експериментальне навчання англійської мови із застосуванням експерієнційної методики проводилося протягом семестру в Інституті прикладного системного аналізу. Авторами описано етапи експериментальної перевірки іiі впровадження на основі нового підручника, в якому пропонується навчання загальної англомовної професіоналізації на основі аспектного підходу. Представлено фактичні результати оцінки ефективності застосування підручника та пропонованої методики для навчання англійської мови студентів напряму підготовки «Системний аналіз». Наведено також результати анкетного опитування студентів, проведеного 3 метою визначення оцінки студентами підручника, методики, навчальних завдань та досягнень у англомовній комунікативній компетентності.

Ключові слова: експерієнційне навчання, загальна англомовна професіоналізація, аспектне викладання.

3. М. Корнева, Ю. В. Павловская. Экспериментальная проверка эффективности использования эксперенциальной методики обучения английскому языку студентов направления подготовки «Системный анализ».

Статья посвящена актуальной проблеме использования эксперенциальной методики в процессе обучения английскому языку в ВУЗах неязыкового профиля. Авторы предлагают использовать вышеуказанную методику для общей англоязычной профессионализации обучения английскому языку, то есть для обеспечения овладения студентами аспектами профессиональной англоязычной коммуникации, общими для большинства неязыковых специальностей. Исходя из компонентного состава англоязычной коммуникативной компетентности, профессионально ориентированный английский язык предлагается изучать аспектно. Среди таких аспектов авторы выделяют предметный, социолингвистический, лингвистический, психологический и коммуникативный аспекты изучения английского языка. Эксперенциальное обучение определяется как обучение через опыт практической деятельности, которая осуществляется средствами изучаемого языка. Авторы описывают этапы экспериментальной проверки ее внедрения на основе нового учебника, в котором предлагается обучение общей англоязычной профессионализации на основе аспектного подхода. Представляются фактические результаты оценки эффективности применения учебника и предлагаемой методики для обучения английскому языку студентов специальности «Системный анализ и управление».

Ключевые слова: эксперенциальное профессионализация, аспектное обучение.

обучение, общая англоязычная 